University of Nebraska - Lincoln

DigitalCommons@University of Nebraska - Lincoln

Publications from USDA-ARS / UNL Faculty

U.S. Department of Agriculture: Agricultural

Research Service, Lincoln, Nebraska

2001

\title{
Net grassland carbon flux over a subambient to superambient CO2 gradient
}

\author{
P. C. Mielnick \\ Texas Agricultural Experiment Station
}

W. A. Dugas

Texas Agricultural Experiment Station

H. B. Johnson

USDA-ARS Grassland, Soil and Water Research Laboratory

H. W. Polley

USDA-ARS Grassland, Soil and Water Research Laboratory, wayne.polley@ars.usda.gov

\section{J. Sanabria}

Texas Agricultural Experiment Station

Follow this and additional works at: https://digitalcommons.unl.edu/usdaarsfacpub

Part of the Agricultural Science Commons

Mielnick, P. C.; Dugas, W. A.; Johnson, H. B.; Polley, H. W.; and Sanabria, J., "Net grassland carbon flux over a subambient to superambient CO2 gradient" (2001). Publications from USDA-ARS / UNL Faculty. 434.

https://digitalcommons.unl.edu/usdaarsfacpub/434

This Article is brought to you for free and open access by the U.S. Department of Agriculture: Agricultural Research Service, Lincoln, Nebraska at DigitalCommons@University of Nebraska - Lincoln. It has been accepted for inclusion in Publications from USDA-ARS / UNL Faculty by an authorized administrator of DigitalCommons@University of Nebraska - Lincoln. 


\title{
Net grassland carbon flux over a subambient to superambient $\mathrm{CO}_{2}$ gradient
}

\author{
P. C. MIELNICK*, W. A. DUGAS*, H. B. JOHNSON†, H. W. POLLEY† and \\ J. S A N A B R I A* \\ *Blackland Research and Extension Center, Texas Agricultural Experiment Station, 720 E. Blackland Road, Temple, TX 76502- \\ 9622, USA, †Grassland, Soil and Water Research Laboratory, USDA, ARS, 808 E. Blackland Road, Temple, TX 76502-9622, \\ USA
}

\begin{abstract}
Increasing atmospheric $\mathrm{CO}_{2}$ concentrations may have a profound effect on the structure and function of plant communities. A previously grazed, central Texas grassland was exposed to a $200-\mu \mathrm{mol} \mathrm{mol}^{-1}$ to $550 \mu \mathrm{mol} \mathrm{mol}{ }^{-1} \mathrm{CO}_{2}$ gradient from March to mid-December in 1998 and 1999 using two, 60-m long, polyethylenecovered chambers built directly onto the site. One chamber was operated at subambient $\mathrm{CO}_{2}$ concentrations (200-360 $\mu \mathrm{mol} \mathrm{mol}^{-1}$ daytime) and the other was regulated at superambient concentrations $\left(360-550 \mu \mathrm{mol} \mathrm{mol}^{-1}\right)$. Continuous $\mathrm{CO}_{2}$ gradients were maintained in each chamber by photosynthesis during the day and respiration at night. Net ecosystem $\mathrm{CO}_{2}$ flux and end-of-year biomass were measured in each of 10, 5-m long sections in each chamber. $\mathrm{Net}^{\mathrm{CO}_{2}}$ fluxes were maximal in late May (c. day 150) in 1998 and in late August in 1999 (c. day 240). In both years, fluxes were near zero and similar in both chambers at the beginning and end of the growing season. Average daily $\mathrm{CO}_{2}$ flux in 1998 was $13 \mathrm{~g}$ $\mathrm{CO}_{2} \mathrm{~m}^{-2}$ day $^{-1}$ in the subambient chamber and $20 \mathrm{~g} \mathrm{CO}_{2} \mathrm{~m}^{-2}$ day $^{-1}$ in the superambient chamber; comparable averages were 15 and $26 \mathrm{~g} \mathrm{CO}_{2} \mathrm{~m}^{-2}$ day $^{-1}$ in 1999. Flux was positively and linearly correlated with end-of-year above-ground biomass but flux was not linearly correlated with $\mathrm{CO}_{2}$ concentration; a finding likely to be explained by inherent differences in vegetation. Because $C_{3}$ plants were the dominant functional group, we adjusted average daily flux in each section by dividing the flux by the average percentage $C_{3}$ cover. Adjusted fluxes were better correlated with $\mathrm{CO}_{2}$ concentration, although scatter remained. Our results indicate that after accounting for vegetation differences, $\mathrm{CO}_{2}$ flux increased linearly with $\mathrm{CO}_{2}$ concentration. This trend was more evident at subambient than superambient $\mathrm{CO}_{2}$ concentrations.
\end{abstract}

Keywords: Canopy $\mathrm{CO}_{2}$ flux, $\mathrm{CO}_{2}$ gradient, grassland

Received 31 October 2000; revised version received 16 March 2001 and accepted 3 May 2001

\section{Introduction}

The direct and indirect effects of increasing atmospheric $\mathrm{CO}_{2}$ may have profound implications for the structure and function of plant communities. Vegetation, in turn, plays a crucial role in the global carbon balance (Woodward et al. 1998). Although numerous greenhouse

Correspondence: W. A. Dugas, 720 E. Blackland Road, Temple, TX 76502-9622, USA, fax +(254) 774 6001, e-mail dugas@brc. tamus.edu and growth chamber studies have been conducted on plant response to superambient atmospheric $\mathrm{CO}_{2}$ concentrations (Diemer 1994; Polley et al. 1996; Field et al. 1997; Schapendonk et al. 1997; Bunce 1998; Diaz et al. 1998), processes controlling plant response to $\mathrm{CO}_{2}$ on these smaller scales (e.g. greenhouse pot studies) may be quite different than those controlling plant responses on a larger scale, such as in the field. The complex effects of competitive resource acquisition (e.g. soil nutrients, light 
and water) in a natural ecosystem are not easily duplicated in smaller scale studies. Few studies have been undertaken on whole ecosystem response to superambient $\mathrm{CO}_{2}$ (Jackson et al. 1994; Fredeen et al. 1997; Hamerlynck et al. 1997; Vasseur \& Potvin 1998), and even less research has been directed towards the effects of subambient $\mathrm{CO}_{2}$ concentrations on vegetation (Polley 1992a, 1992b; Polley et al. 1996). Evaluating plant responses in the field under both subambient and superambient $\mathrm{CO}_{2}$ concentrations will help interpret effects of past $\mathrm{CO}_{2}$ changes on vegetation, and may improve prediction of future responses of ecosystems to $\mathrm{CO}_{2}$ concentrations.

Two commonly used facilities for outdoor $\mathrm{CO}_{2}$ studies, open top chambers and Free Air Carbon Dioxide Enrichment (FACE) devices, use a limited number of $\mathrm{CO}_{2}$ concentrations (Diemer 1994; Jackson et al. 1994; Lewin et al. 1994; Fredeen et al. 1997; Hamerlynck et al. 1997; Hungate et al. 1997a, 1997b). Covered chambers have been used in a greenhouse to evaluate plant responses over a wide range of subambient $\mathrm{CO}_{2}$ concentrations (Polley et al. 1992a, 1992b). Here, we extended the use of a covered chamber outdoors to a Texas grassland to measure net ecosystem $\mathrm{CO}_{2}$ flux continuously for two growing seasons. Our study is, we believe, the first to investigate plant responses over a continuum of subambient to superambient atmospheric $\mathrm{CO}_{2}$ concentrations in a natural plant community. The canopy level flux measurements in this study complement concomitant work at the leaf-level scale (Anderson et al. 2001).

The objective of this study was to quantify relationships between $\mathrm{CO}_{2}$ flux and both $\mathrm{CO}_{2}$ concentration and biomass for a Texas grassland exposed to a 200-550 $\mu \mathrm{mol}$ $\mathrm{mol}^{-1} \mathrm{CO}_{2}$ gradient from early March to mid-December in 1998 and 1999.

\section{Materials and methods}

Johnson et al. (2000) present a complete description of the experimental apparatus and sampling protocol. A brief summary is presented here.

\section{Chamber and site description}

The research site was a previously grazed grassland at the Grassland, Soil and Water Research Laboratory in central Texas, USA $\left(31^{\circ} 05^{\prime} \mathrm{N}, 97^{\circ} 20^{\prime} \mathrm{W}\right)$. Vegetation is dominated by the $\mathrm{C}_{4}$ perennial grass Bothriochloa ischaemum (L.) Keng (King Ranch bluestem) and the $\mathrm{C}_{3}$ perennial forbs Solanum dimidiatum (Raf.) (Western horsenettle) and Ratibida columnaris (Sims) D. Don (Mexican hat). Soil is in the Austin series (a mollisol) and is classified as a fine-silty, carbonatic, thermic, Udorthentic Haplustoll with $35-55 \%$ clay in the top $40 \mathrm{~cm}$. Inclusions of the Houston Black series (a vertisol defined as a fine, smectitic, thermic Udic Haplustert) are common. Extensive sampling has shown that the soil varies horizontally and vertically over short distances, a characteristic of this soil type. Prior to fabrication of the chambers, soil cores (depth $1.7 \mathrm{~m}$, diameter $40 \mathrm{~mm}$ ) were taken at the centre of each section ( $n=20$, see below). Roots were removed from each core and total root biomass was determined. Measured rooting depth exceeded one meter throughout both chambers. To examine if soil variation affected root biomass, we regressed total root biomass against subsequent $\mathrm{CO}_{2}$ concentration. Regression slopes were not significantly different from zero $(P>0.2$ and $P>0.6$ over subsequent superambient and subambient concentration gradients, respectively). Thus, we conclude that soil variation did not affect root biomass prior to $\mathrm{CO}_{2}$ treatments.

Two, parallel, 60-m long chambers, enclosed by polyethylene film, were built $1.5 \mathrm{~m}$ apart on the site in a north-south orientation. The film transmitted $90 \%$ of incident photosynthetically active radiation (Johnson et al. 2000). Each chamber was divided into a series of 5-m long sections (numbered 1 through 10, south to north, in the superambient chamber, and 11 through 20 in the subambient chamber), separated by $1-\mathrm{m}$ long metal ducts containing chilled-water cooling coils that regulated air temperature and humidity. Chamber soil was isolated with a 1-m deep plastic liner extending vertically into the soil.

$\mathrm{CO}_{2}$ uptake by plants during daylight depleted the $\mathrm{CO}_{2}$ concentration of air as it was blown with a fan through each chamber from south to north, thus creating a continuous $\mathrm{CO}_{2}$ gradient with highest concentrations at the south end and lowest concentrations at the north end. In the superambient chamber, $\mathrm{CO}_{2}$ was injected into entering air during daylight hours to enrich the $\mathrm{CO}_{2}$ concentration to $550 \mu \mathrm{mol} \mathrm{mol}{ }^{-1}$ in section 1 . The air exited at the north end at $360 \mu \mathrm{mol} \mathrm{mol}{ }^{-1}$ (section 10). Ambient air was introduced to the south end of the subambient chamber to initiate a 360 (section 11) to $200 \mu \mathrm{mol} \mathrm{mol}{ }^{-1}$ (section 20) gradient.

The direction of air flow was reversed at night and $\mathrm{CO}_{2}$ concentration increased along each chamber because of plant and soil respiration. $\mathrm{CO}_{2}$ was injected at night at the north end of the superambient chamber to increase the initial $\mathrm{CO}_{2}$ concentration to $550 \mu \mathrm{mol} \mathrm{mol}{ }^{-1}$. Nighttime $\mathrm{CO}_{2}$ concentrations were maintained in each section at $150 \mu \mathrm{mol} \mathrm{mol} \mathrm{m}^{-1}$ above daytime levels. The $\mathrm{CO}_{2}$ concentration gradient was imposed from April through mid-December in 1997 and from March through midDecember in 1998 and 1999. 


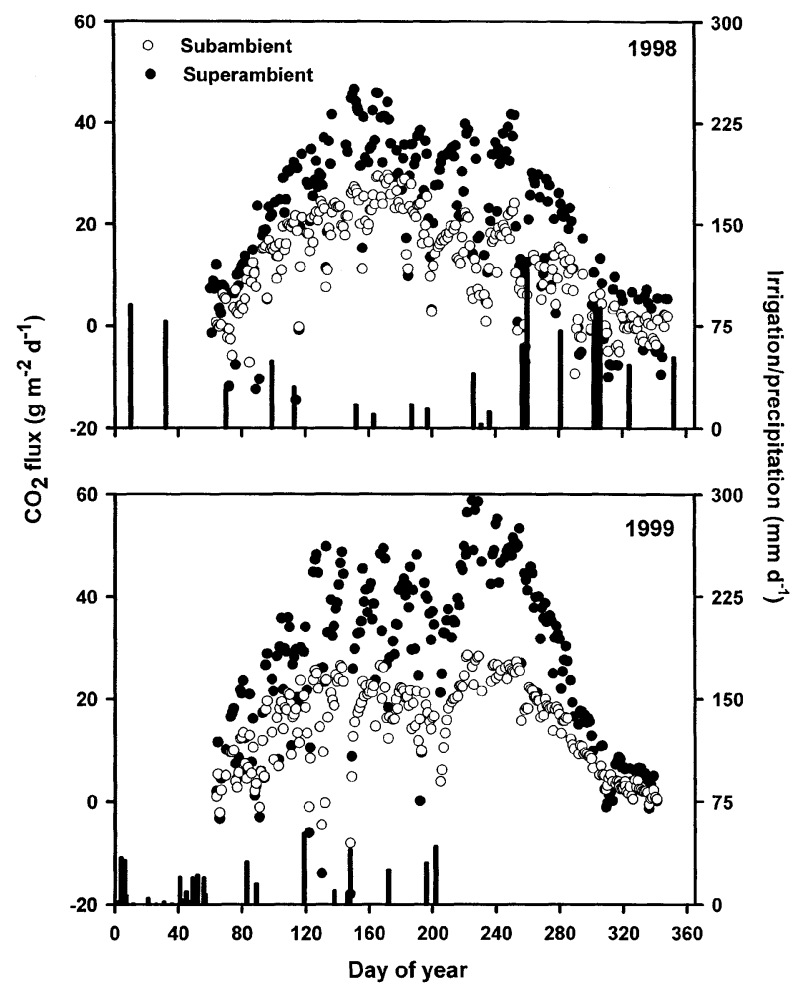

Fig. 1 Daily $\mathrm{CO}_{2}$ flux for subambient and superambient chambers and daily irrigation or precipitation in 1998 and 1999. Fluxes are averages of 10 sections per chamber.

\section{Precipitation/irrigation}

The chambers received any precipitation that fell when they were uncovered (i.e. from mid-December to early March and during a single, daylight period each month for vegetation measurements); all other water was supplied by irrigation. The total amount of water applied (irrigation plus precipitation) was $996 \mathrm{~mm}$ in 1998 and $337 \mathrm{~mm}$ in 1999. The 87-year annual average precipitation at the site is $864 \mathrm{~mm}$.

\section{$\mathrm{CO}_{2}$ flux measurements}

Twenty-minute averages of net ecosystem $\mathrm{CO}_{2}$ flux (positive $=\mathrm{CO}_{2}$ uptake) for each 5-m section were calculated as a product of the average $\mathrm{CO}_{2}$ gradient and average air flow rate in each section. The gradient was the difference in $\mathrm{CO}_{2}$ concentration between the south and north ends of each section. Concentrations were measured, sequentially, within each chamber, once every 20 minutes during the final $20 \mathrm{~s}$ of a 1 minute sampling period using an infra-red gas analyser (Model 6262, Li-Cor, Inc, Lincoln, NE, USA). A separate analyser was used for each chamber. Air flow rate $\left(\mathrm{L} \mathrm{s}^{-1}\right)$ was the product of the fan revolutions and a set of regression coefficients calculated for each section and flow direction. Coefficients were calculated during periodic calibrations using independent volumetric flow calculations at varying fan speeds. The same set of coefficients was used for each section for both years because coefficients varied by less than $10 \%$ between calibrations.

Net ecosystem $\mathrm{CO}_{2}$ flux was calculated from day 60 to day 348 in 1998 and from day 64 to day 341 in 1999. Total daily fluxes were calculated as the sum of 20-minute fluxes. Fewer than $1 \%$ of seasonal 20-minute fluxes were linearly interpolated, usually due to spurious fluxes that sometimes occurred at dawn and dusk when flow direction changed. Occasionally, daily fluxes were unavailable due to malfunctioning equipment or when chambers were uncovered for vegetation measurements. Across all sections, flux was measured for an average of 254 and 236 days in 1998 and 1999, respectively. Average daily fluxes for the season were calculated from all daily fluxes; missing days (due to tunnel maintenance, calibrations, or temporary equipment malfunction) were ignored.

\section{Above-ground biomass and vegetative cover}

Above-ground biomass (including live and standing dead but excluding litter) in each section was harvested (to $5 \mathrm{~cm}$ ), oven-dried and weighed in December of 1998 and 1999. The percentage green vegetative cover, by species, was determined monthly by visual inspection in two $1 \times 1 \mathrm{~m}$ quadrats per section. Species were grouped into either $C_{3}$ or $C_{4}$ functional classes. The seasonal average percentage $C_{3}$ cover was used as an index of vegetative differences between sections and years.

\section{Data analysis}

For each 5-m section, average daily $\mathrm{CO}_{2}$ flux for the season was regressed against average daytime $\mathrm{CO}_{2}$ concentration and end-of-season above-ground biomass. To validate measured $\mathrm{CO}_{2}$ fluxes, we compared seasonal average daily $\mathrm{CO}_{2}$ flux for each section with an equivalent $\mathrm{CO}_{2}$ flux calculated from end-of-season biomass measurements in each section using the following assumptions: above-ground live biomass was zero at the beginning of each year, $1 \mathrm{~g}$ of oven-dried organic matter equals $1.5 \mathrm{~g}$ of $\mathrm{CO}_{2}$ (Larcher 1975), and the average root : shoot ratio was 3:1 (based upon root measurements in an adjacent grassland; Dugas, unpublished data 2000). This is consistent with measured ratios in grasslands that range from 2:1 and 4:1 (Svejcar 1990). 


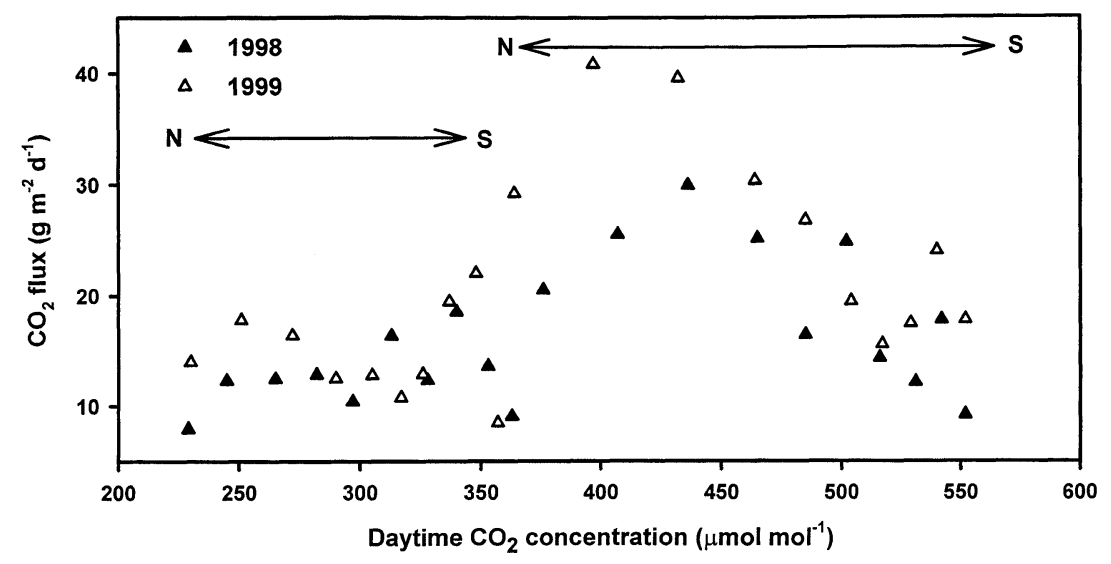

Fig. 2 Average daily $\mathrm{CO}_{2}$ flux vs. average daytime $\mathrm{CO}_{2}$ concentration in 1998 and 1999. Averages are for all days in a year. North and south ends of subambient and superambient chambers are indicated.

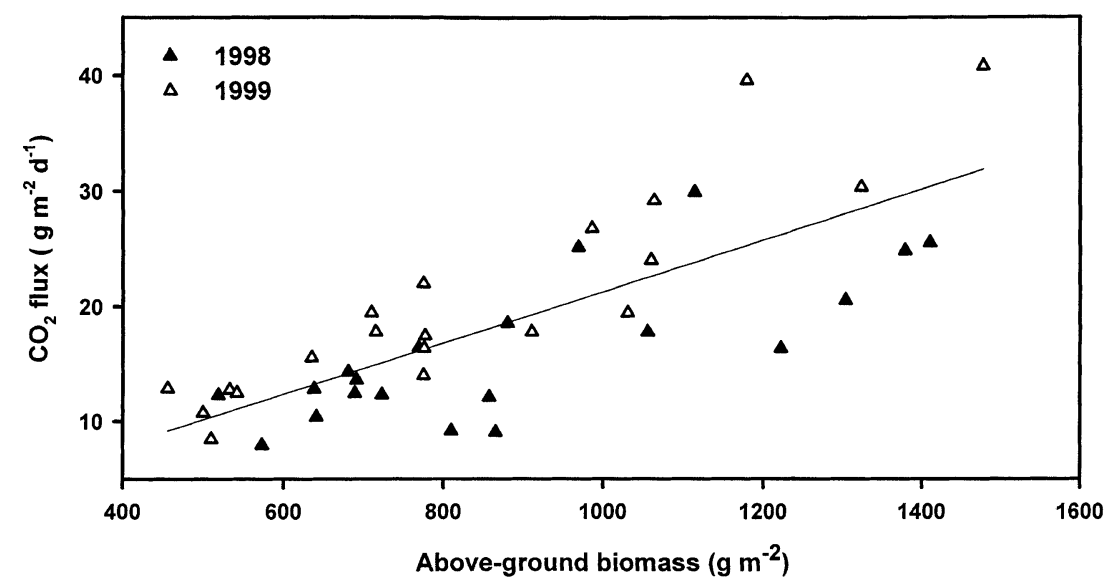

Fig. 3 Average daily $\mathrm{CO}_{2}$ flux vs. end-of-year, above-ground biomass for all sections of both chambers in 1998 and $1999 . R^{2}=0.60$.

\section{Results}

\section{Daily $\mathrm{CO}_{2}$ fluxes}

Daily $\mathrm{CO}_{2}$ fluxes (averaged across 10 sections in each chamber) were lower over subambient than superambient $\mathrm{CO}_{2}$ concentrations during much of the growing season in both 1998 and 1999 (Fig. 1). Most day-to-day variability in flux reflected changes in radiation, whereas seasonal changes in flux were related to changes in leaf area, phenology or soil moisture. At the beginning and end of each growing season, fluxes were near zero and were similar over both superambient and subambient $\mathrm{CO}_{2}$ concentrations. As the season progressed, fluxes increased and there was a widening separation between superambient and subambient fluxes. Maximum flux occurred in late May (c. day 150) in 1998 and in late August (c. day 240) in 1999.
Recovery time of net $\mathrm{CO}_{2}$ uptake following exposure to high temperatures or drought differed between subambient and elevated concentrations in both years. Daily $\mathrm{CO}_{2}$ fluxes at superambient $\mathrm{CO}_{2}$ concentrations recovered faster from heat and drought stress than fluxes at subambient $\mathrm{CO}_{2}$ concentrations. For example, in 1998, following a 2-h exposure to temperatures $>45^{\circ} \mathrm{C}$ on day 199 , fluxes at superambient $\mathrm{CO}_{2}$ concentrations recovered $30 \%$ faster over the next 5 days than did fluxes at subambient $\mathrm{CO}_{2}$ concentrations. In 1999, following a total irrigation of $72 \mathrm{~mm}$ on days 196 and 202 (mid-July) after a 24-day drought, net $\mathrm{CO}_{2}$ uptake increased $25 \%$ faster over the next 6 days at superambient compared to subambient $\mathrm{CO}_{2}$ concentrations.

The decline in daily $\mathrm{CO}_{2}$ flux after day 240 in both 1998 and 1999 (Fig. 1) can be attributed to senescing vegeta- 


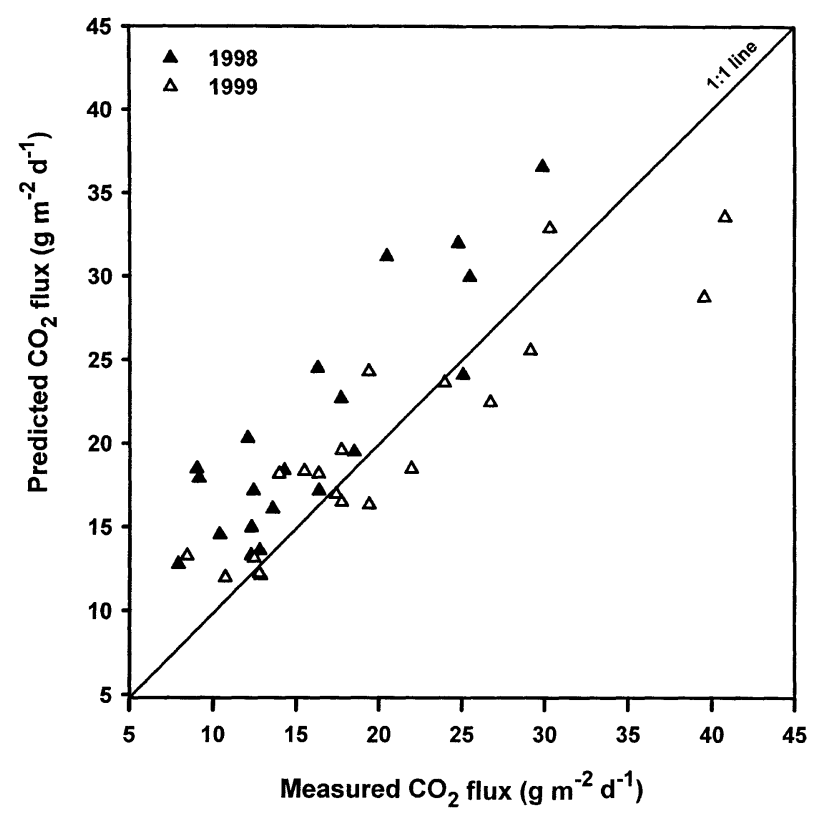

Fig. 4 Predicted vs. measured $\mathrm{CO}_{2}$ flux in 1998 and 1999. Measured fluxes are averages for all days in a year. Predicted fluxes were calculated from end-of-year above-ground biomass and a root : shoot ratio of $3: 1$ (see text).

tion. The decrease is steeper in 1999, a situation likely to have been caused by soil moisture declining more rapidly in this year because of late season drought. Average daily $\mathrm{CO}_{2}$ flux in 1998 was 13 and $20 \mathrm{~g} \mathrm{CO}_{2} \mathrm{~m}^{-2}$ day $^{-1}$ in the subambient and superambient $\mathrm{CO}_{2}$ chambers, respectively. In 1999, comparable averages were 15 and $26 \mathrm{~g} \mathrm{CO}_{2} \mathrm{~m}^{-2}$ day $^{-1}$.

\section{Flux vs. $\mathrm{CO}_{2}$ concentration}

There was a greater than three-fold difference in average daily flux among chamber sections in both years (Fig. 2). In 1998, average daily $\mathrm{CO}_{2}$ flux ranged from $8 \mathrm{~g} \mathrm{CO}_{2} \mathrm{~m}^{-2}$ day $^{-1}$ at $229 \mu \mathrm{mol} \mathrm{mol}{ }^{-1}$ to $30 \mathrm{~g} \mathrm{CO}_{2} \mathrm{~m}^{-2} \mathrm{day}^{-1}$ at $436 \mu \mathrm{mol} \mathrm{mol}^{-1}$. In 1999, flux ranged from $8 \mathrm{~g} \mathrm{CO}_{2} \mathrm{~m}^{-2}$ day $^{-1}$ at $357 \mu \mathrm{mol} \mathrm{mol}{ }^{-1} \mathrm{CO}_{2}$ to $41 \mathrm{~g} \mathrm{CO}_{2} \mathrm{~m}^{-2}$ day $^{-1}$ at $397 \mu \mathrm{mol} \mathrm{mol}{ }^{-1} \mathrm{CO}_{2}$. Generally, fluxes in each section were greater in 1999 than 1998.

There was a parabolic relationship between flux and $\mathrm{CO}_{2}$ concentration with a maximum flux at about $400 \mu \mathrm{mol} \mathrm{mol}{ }^{-1} \mathrm{CO}_{2}$ in both years. Over subambient $\mathrm{CO}_{2}$ concentrations, fluxes increased with increasing $\mathrm{CO}_{2}$ concentration, especially above $300 \mu \mathrm{mol} \mathrm{mol}^{-1}$. However, flux decreased with $\mathrm{CO}_{2}$ concentration $>450 \mu \mathrm{mol} \mathrm{mol}^{-1}$ in the superambient chamber, a result opposite that which was expected.

\section{Flux vs. above-ground biomass}

In both years, average daily $\mathrm{CO}_{2}$ flux was linearly and positively correlated with end-of-year, above-ground biomass (Fig. 3). Measured $\mathrm{CO}_{2}$ fluxes were similar to biomass-predicted fluxes in 1999 and slightly less than predicted fluxes in 1998 (Fig. 4). The close relationship between measured and predicted $\mathrm{CO}_{2}$ fluxes gives additional support to the accuracy of these fluxes, especially considering that our estimated $3: 1$ root : shoot ratio is consistent with published root : shoot measurements in grasslands.

\section{Vegetation heterogeneity}

Relative abundances of $\mathrm{C}_{3}$ and $\mathrm{C}_{4}$ species varied both spatially and temporally (Fig. 5). Clearly, over time, $C_{3}$ vegetation increased at the expense of $C_{4}$ vegetation. From 1997 to 1999 , cover of $C_{3}$ species increased by $71 \%$ and $63 \%$, while cover of $\mathrm{C}_{4}$ species decreased by $77 \%$ and $52 \%$ over subambient and superambient $\mathrm{CO}_{2}$ concentrations, respectively. Variation in vegetation among sections was great in each year; coefficients of variation among sections were greater than $30 \%$ and $40 \%$ for $C_{3}$ and $\mathrm{C}_{4}$ species, respectively, in all three years. Aggressive, tall, early growing and relatively long-lived $\mathrm{C}_{3}$ species like $R$. columnaris, Solidago canadensis (L.) (goldenrod) and $S$. dimidiatum increased in cover from 1997 to 1999 (results not shown). Over subambient $\mathrm{CO}_{2}$ concentrations, percentage cover of the initially dominant $\mathrm{C}_{4}$ grass $B$. ischaemum declined from an average of $46 \%$ in 1997 to less than 9\% in 1999, and at superambient concentrations cover declined from $40 \%$ to $17 \%$. However, another $\mathrm{C}_{4}$ grass, Sorghum halepense (L.) Pers. (Johnsongrass), was one of a quartet of dominant species (including $R$. columnaris, S. canadensis and S. dimidiatum) in some sections in the superambient chamber. The total number of species in this grassland varied between 11 and 29 per section. The turnover rate of species (ratio of appearance to disappearance of species from year to year) was high between years, but was not related to $\mathrm{CO}_{2}$ flux, above-ground biomass or $\mathrm{CO}_{2}$ concentration (data not shown).

\section{Adjusting flux}

To standardize fluxes for vegetation changes among sections within each year, we divided the average daily flux by the percentage cover of $C_{3}$ plants, the dominant vegetative group at both the subambient and superambient $\mathrm{CO}_{2}$ concentrations (Fig. 5). Average daily $\mathrm{CO}_{2}$ fluxes were positively related to percentage $C_{3}$ cover $(P<0.0001)$ over all concentrations (results not shown). This standardization improved the relationship between 


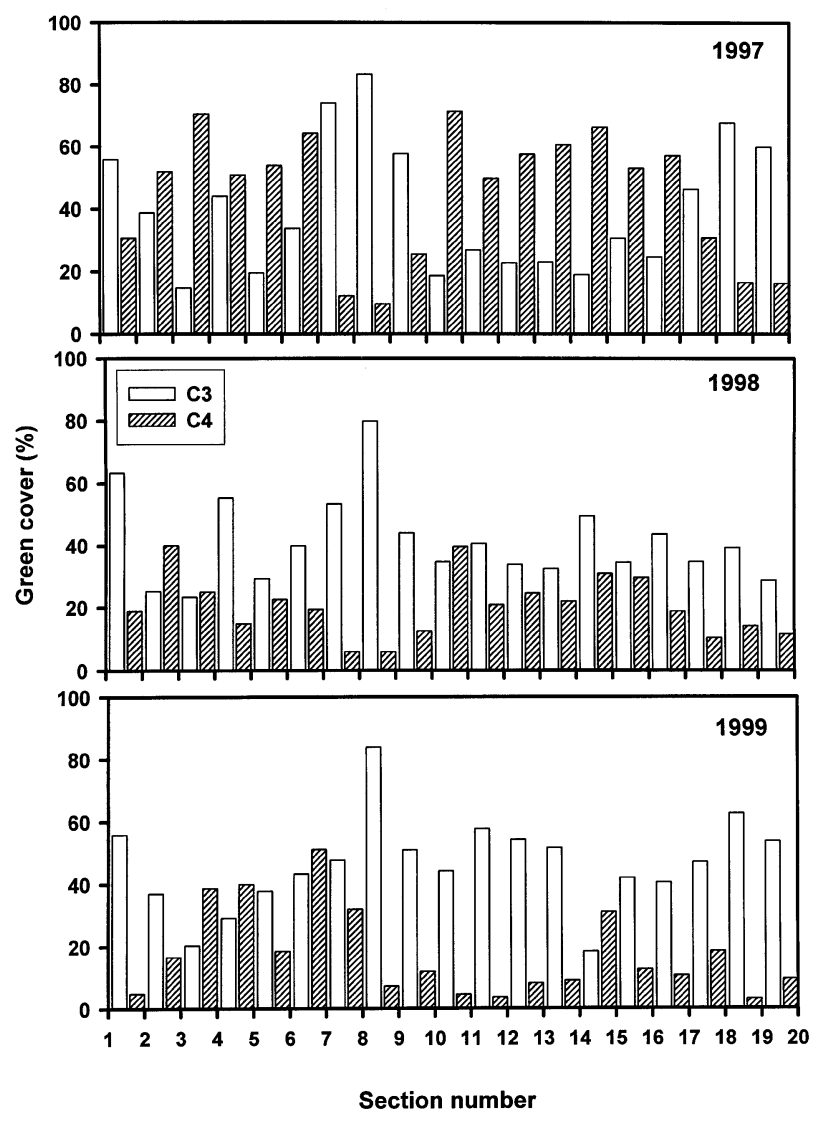

Fig. 5 Percentage green $C_{3}$ and $C_{4}$ vegetation cover in 1997, 1998 and 1999 for each section. $\left(\mathrm{CO}_{2}\right.$ concentration varied from $550 \mu \mathrm{mol} \mathrm{mol}{ }^{-1}$ in section 1 to $230 \mu \mathrm{mol} \mathrm{mol}^{-1}$ in section 20). Percentage cover is an average of all monthly vegetation observations within a year.

flux and $\mathrm{CO}_{2}$ concentration across the full $\mathrm{CO}_{2}$ gradient (Fig. 6), although substantial scatter remained.

\section{Discussion}

After accounting for some of the variability in vegetation in this grassland, results show that $\mathrm{CO}_{2}$ flux increased with increasing $\mathrm{CO}_{2}$ concentration. Some of the remaining scatter may reflect differences in $\mathrm{C}_{4}$ composition or other vegetation and/or soil differences not accounted for by this procedure (although initial root biomass did not differ with section position). There was a good relationship between $\mathrm{CO}_{2}$ flux and above-ground biomass in both years, and between measured and predicted fluxes (Figs 3 and 4), although fluxes were high compared to $\mathrm{CO}_{2}$ fluxes measured in other grasslands. For example, fluxes of $9.3 \mathrm{~g} \mathrm{CO}_{2} \mathrm{~m}^{-2}$ day $^{-1}$ and $11.4 \mathrm{~g}$ $\mathrm{CO}_{2} \mathrm{~m}^{-2}$ day $^{-1}$ were measured during July and August in a $\mathrm{C}_{4}$ grassland in Kansas under ambient and superambient $\mathrm{CO}_{2}$ concentrations, respectively (Ham et al.

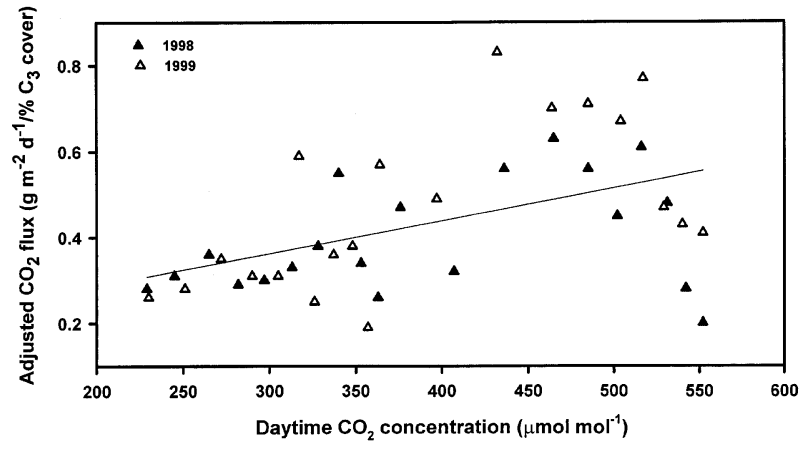

Fig. 6 Average daily $\mathrm{CO}_{2}$ flux, adjusted for average percentage $\mathrm{C}_{3}$ cover vs. average daytime $\mathrm{CO}_{2}$ concentration in 1998 and 1999. $R^{2}=0.23$.

1995). Two-year average $\mathrm{CO}_{2}$ fluxes in this study over the same time period (Fig. 1) were $21 \mathrm{~g}$ and $35 \mathrm{~g} \mathrm{CO}_{2} \mathrm{~m}^{-2}$ day $^{-1}$ over subambient and superambient $\mathrm{CO}_{2}$ concentrations, respectively. Our fluxes likely were high because of the protective environment inside the covered chambers compared to the outside environment (i.e. reduced wind and vapour pressure deficit, increased diffuse light (Johnson et al. 2000) and reduced insect herbivory) and a long growing season.

Community-level flux response to increasing $\mathrm{CO}_{2}$ levels was strongly influenced by vegetation differences. We suggest the non-linear relationship of flux to $\mathrm{CO}_{2}$ concentration (Fig. 2) was due to initial differences in vegetation and differences that developed with time (Fig. 5). $C_{3}$ and $C_{4}$ species have different growth and rooting patterns, plant architecture, seasonal production cycles and physiological parameters (Bazzaz \& McConnaughay 1992; Owensby et al. 1993; Poorter 1993; Coviella \& Trumble 1998), and may respond differently to $\mathrm{CO}_{2}$ treatments (Campbell et al. 1995; Drake \& Gonzales-Meler 1997; Collatz et al. 1998; Wand et al. 1999). The $C_{3}$ species at our site appeared to be more competitive for light, water and nutrients, regardless of $\mathrm{CO}_{2}$ treatment. These characteristics led to an alteration in the $C_{3}$ and $C_{4}$ dominance hierarchy that manifested itself, over time, as a consistent decline in the proportion of $\mathrm{C}_{4}$ species relative to $\mathrm{C}_{3}$ species (Fig. 5). Among $\mathrm{C}_{4}$ species, only $S$. halapense, a grass species that possesses many competitive attributes such as early growth and tallness, appeared to proliferate. Some of the highest $\mathrm{CO}_{2}$ fluxes in both years occurred at $397 \mu \mathrm{mol} \mathrm{mol}^{-1}$, where vegetation has maintained a consistently high and stable proportion of percentage $C_{3}$ cover (section 9, Fig. 5) and where the dominant $C_{3}$ species Lippia nodiflora (L.) Michx. (frogfruit) and R. columnifera changed little over time.

Accounting for differences in $\mathrm{C}_{3}$ composition improved the fit of the relationship between $\mathrm{CO}_{2}$ flux 
and $\mathrm{CO}_{2}$ concentration (Fig. 6). The relatively strong relationship between adjusted flux and $\mathrm{CO}_{2}$ concentration at subambient concentrations suggests fluxes at these concentrations may have been limited by atmospheric $\mathrm{CO}_{2}$.

The variability in species composition at this site is not unusual and reflects conditions often found in natural grasslands (Hungate et al. 1997a, 1997b; Reynolds et al. 1997; Braakhekke \& Hooftman 1999) and probably in other ecosystems as well. Some of the variation in vegetation in this experiment could have resulted from $\mathrm{CO}_{2}$ treatment as well as site history. The relationship between ecosystem $\mathrm{CO}_{2}$ fluxes and $\mathrm{CO}_{2}$ concentration differed from that of leaf-level fluxes and $\mathrm{CO}_{2}$ treatment. Anderson et al. (2001) found a positive, linear photosynthetic response of leaves of 3 species to $\mathrm{CO}_{2}$ over subambient to superambient concentrations. Canopy level flux measurements cannot, however, detect a species-specific response to $\mathrm{CO}_{2}$ treatment. Thus, canopy fluxes may have been influenced by a disproportionate response of a few, highly responsive species (Navas 1998). Nevertheless, these results clearly illustrate that one must use caution when scaling up results from $\mathrm{CO}_{2}$ experiments at the leaf- or single-plant level to intact, multi-species ecosystems.

\section{Acknowledgements}

We thank Ron Whitis for design and maintenance of the chambers, Anne Gibson for measurement and initial analysis of vegetation data, and Catherine Miller for quality control on the flux data.

\section{References}

Anderson LH, Maherali H, Johnson HB, Polley HW, Jackson RB, (2001) Gas exchange and photosynthetic acclimation over subambient to elevated $\mathrm{CO}_{2}$ in a $\mathrm{C}_{3}-\mathrm{C}_{4}$ grassland. Global Change Biology (in press).

Bazzaz FA, McConnaughay KD (1992) Plant-plant interactions in elevated $\mathrm{CO}_{2}$ environments. Australian Journal of Botany, 40, 547-563.

Braakhekke WG, Hooftman DAP (1999) The resource balance hypothesis of plant species diversity in grassland. Journal of Vegetation Science, 10, 187-200.

Bunce JA (1998) Effects of humidity on short-term responses of stomatal conductance to an increase in carbon dioxide concentration. Plant, Cell and Environment, 21, 115-120.

Campbell BD, Laing WA, Greer DH, Crush JR, Clark H, Williamson DY, Given MDJ (1995) Variation in grassland populations and species and the implications for community responses to elevated $\mathrm{CO}_{2}$. Journal of Biogeography, 22, 315-322.

Collatz GJ, Berry JA, Clark JS (1998) Effects of climate and atmospheric $\mathrm{CO}_{2}$ partial pressure on the global distribution of $\mathrm{C}_{4}$ grasses: present, past, and future. Oecologia, 114, 441-454.

Coviella CE, Trumble JT (1998) Effects of superambient atmo- spheric carbon dioxide on insect-plant interactions. Conservation Biology, 13, 700-712.

Diaz S, Fraser LH, Grime JP, Falczuk V (1998) The impact of superambient $\mathrm{CO}_{2}$ on plant-herbivore interactions: experimental evidence of moderating effects at the community level. Oecologia, 117, 177-186.

Diemer MW (1994) Mid-season gas exchange of an alpine grassland under superambient $\mathrm{CO}_{2}$. Oecologia, 98, 429-435.

Drake BG, Gonzales-Meler MA (1997) More efficient plants: a consequence of rising atmospheric $\mathrm{CO}_{2}$ ? Annual Review Plant Physiology and Plant Molecular Biology, 48, 609-639.

Field CB, Lund CP, Chiariello NR, Mortimer BE (1997) $\mathrm{CO}_{2}$ effects on the water budget of grassland microcosm communities. Global Change Biology, 3, 197-206.

Fredeen AL, Randerson JT, Holbrook NM, Field CB (1997) Superambient atmospheric $\mathrm{CO}_{2}$ increases water availability in a water-limited grassland ecosystem. Journal of the American Water Resources Association, 33, 1033-1039.

Ham JM, Owensby CE, Coyne PI, Bremer DJ (1995) Fluxes of $\mathrm{CO}_{2}$ and water vapor from a prairie ecosystem exposed to ambient and superambient atmospheric $\mathrm{CO}_{2}$. Agricultural and Forest Meteorology, 77, 73-93.

Hamerlynck EP, McAllister CA, Knapp AK, Ham JM, Owensby CE (1997) Photosynthetic gas exchange and water relation responses of three tallgrass prairie species to superambient carbon dioxide and moderate drought. International Journal of Plant Science, 158 (5), 608-616.

Hungate BA, Chapin FS, Zhong H, Holland EA, Field CB (1997b) Stimulation of grassland nitrogen cycling under carbon dioxide enrichment. Oecologia, 109, 149-253.

Hungate BA, Holland EA, Jackson RB, Chapin FS, Mooney HA, Field CB (1997a) The fate of carbon in grasslands under carbon dioxide enrichment. Nature, 388, 576-579.

Jackson RB, Sala OE, Field CB, Mooney HA (1994) $\mathrm{CO}_{2}$ alters water use, carbon gain, and yield for the dominant species in a natural grassland. Oecologia, 98, 257-262.

Johnson HB, Polley HW, Whitis RP (2000) Elongated chambers for field studies across atmospheric $\mathrm{CO}_{2}$ gradients. Functional Ecology, 14, 388-396.

Larcher W (1975) Physiological Plant Ecology. Springer-Verlag, New York, USA. 253 pp.

Lewin K, Hendrey GR, Nagy J, LaMorte RL (1994) Design and application of a free-air carbon dioxide enrichment facility. Agricultural and Forest Meteorology, 70, 15-29.

Navas ML (1998) Individual species performance and response of multi-specific communities to elevated $\mathrm{CO}_{2}$ : a review. Functional Ecology, 12, 721-727.

Owensby CE, Coyne PI, Ham JM, Auen LM, Knapp AK (1993) Biomass production in a tallgrass prairie ecosystem exposed to ambient and superambient $\mathrm{CO}_{2}$. Ecological Applications, 3, 644-653.

Polley HW, Johnson HB, Mayeux HS (1992a) Carbon dioxide and water fluxes of $\mathrm{C}_{3}$ annuals and $\mathrm{C}_{3}$ and $\mathrm{C}_{4}$ perennials at subambient $\mathrm{CO}_{2}$ concentrations. Functional Ecology, 6, 693-703.

Polley HW, Johnson HB, Mayeux HS (1992b) Growth and gas exchange of oats (Avena sativa) and wild mustard (Brassica kaber) at subambient $\mathrm{CO}_{2}$ concentrations. International Journal of Plant Science, 153, 453-461.

Polley HW, Johnson HB, Mayeux HS, Brown DA, White JW (1996) Leaf and plant water use efficiency of $C_{4}$ species grown 
754 P. C. M IE L N ICK et al.

at glacial to superambient $\mathrm{CO}_{2}$ concentrations. International Journal of Plant Science, 157, 164-170.

Poorter H (1993) Interspecific variation in the growth response of plants to an elevated ambient $\mathrm{CO}_{2}$ concentration. Vegetatio, 104/105, 77-997.

Reynolds HL, Hungate BA, Chapin FS, D'Antonio CM (1997) Soil heterogeneity and plant competition in an annual grassland. Ecology, 78, 2076-2090.

Schapendonk AHCM, Dijkstra P, Groenwold J, Pot CS, Van de Geijn SC (1997) Carbon balance and water use efficiency of frequently cut Lolium perenne L. swards at superambient carbon dioxide. Global Change Biology, 3, 207-216.

Svejcar TJ (1990) Response of Andropogon gerardii to fall in the tallgrass prairie. In: Fire in North American Tallgrass Prairies (eds. Collins SL, Wallace LL), pp. 20-27, University of Oklahoma Press, Norman, OK, USA.

Vasseur L, Potvin C (1998) Natural pasture community response to enriched carbon dioxide atmosphere. Plant Ecology, 135, 31-41.

Wand SJ, Midgley GF, Jones MH, Curtis PS (1999) Responses of wild $\mathrm{C}_{4}$ and $\mathrm{C}_{3}$ grass (Poaceae) species to superambient atmospheric $\mathrm{CO}_{2}$ concentration: a meta-analytic test of current theories and perceptions. Global Change Biology, 5, 723-741.

Woodward FI, Lomas MR, Betts RA (1998) Vegetation-climate feedbacks in a greenhouse world. Philosophical Transactions of the Royal Society, London, 353, 29-39. 